DOI: $10.15193 /$ zntj/2017/111/186

\author{
ALICJA ZACHARA, DOROTA GAŁKOWSKA, LESŁAW JUSZCZAK
}

\title{
WYSTĘPOWANIE WIELOPIERŚCIENIOWYCH WĘGLOWODORÓW AROMATYCZNYCH W WYBRANYCH PRODUKTACH ZBOŻOWYCH
}

\author{
Streszczenie
}

W pracy przedstawiono wyniki badań, których celem było określenie poziomu zanieczyszczenia różnych rodzajów produktów zbożowych związkami z grupy wielopierścieniowych węglowodorów aromatycznych (WWA), tj. benzo(a)pirenem oraz sumą benzo(a)pirenu, benzo(a)antracenu, benzo(b)fluorantenu i chryzenu. Zawartość tych związków w produktach przeznaczonych dla niemowląt i małych dzieci jest limitowana przez Rozporządzenie Komisji (UE) 2015/1125. Materiał badany stanowiły dostępne handlowo płatki zbożowe, kasze, chleby, pieczywo chrupkie oraz musli, a także produkty dla niemowląt i dzieci: kaszki zbożowe i mleczno-zbożowe. Oznaczenie WWA przeprowadzono techniką wysokosprawnej chromatografii cieczowej z detekcją fluorymetryczną (HPLC-FLD) po uprzednim zmydleniu próbek oraz wyekstrahowaniu i oczyszczeniu frakcji węglowodorowej. Wyznaczone na etapie walidacji metody wartości granicy wykrywalności i granicy oznaczalności wynosiły odpowiednio: $0,18 \mu \mathrm{g} / \mathrm{kg}$ oraz $0,25 \mu \mathrm{g} / \mathrm{kg}$ i były znacznie niższe od odpowiednich wartości maksymalnych określonych w Rozporządzeniu Komisji (UE) nr 836/2011. W $73 \%$ produktów zbożowych wykryto obecność badanych poliarenów, przy czym ich zawartość nie przekraczała $1 \mu \mathrm{g} / \mathrm{kg}$. W próbkach płatków kukurydzianych oraz chlebów stwierdzono mniejsze zawartości sumy czterech WWA niż w próbkach kaszy, pieczywa chrupkiego i musli. Benzo(a)antracen, benzo(b)fluoranten i chryzen wykryto w $20 \%$ badanych kaszek dla niemowląt i dzieci, natomiast w żadnej z nich nie wykryto benzo(a)pirenu.

Słowa kluczowe: wielopierścieniowe węglowodory aromatyczne (WWA), benzo(a)piren, produkty zbożowe, żywność dla dzieci

\section{Wprowadzenie}

Wielopierścieniowe węglowodory aromatyczne (WWA), obok takich związków jak mikotoksyny, nitrozoaminy, dioksyny, a także heterocykliczne aminy aromatyczne

Mgr inż. A. Zachara, dr inż. D. Gałkowska, prof. dr hab. inż. L. Juszczak, Katedra Analizy i Oceny Jakości Żywności, Wydz. Technologii Żywności, Uniwersytet Rolniczy w Krakowie, ul. Balicka 122, 31-149 Kraków. Kontakt: azachara@poczta.onet.pl 
(HAA), należą do najbardziej aktywnych związków rakotwórczych występujących w żywności [15]. WWA występują powszechnie w środowisku (w powietrzu, w wodzie, w glebie) oraz w żywności. Związki te mogą dostawać się do organizmu ludzkiego drogą pokarmową, inhalacyjną oraz przez skórę. Zanieczyszczenie żywności WWA jest skutkiem zarówno zanieczyszczenia środowiska (katastrofy ekologiczne, wybuchy wulkanów, pożary, tzw. „niska emisja”), jak i procesów przetwarzania żywności (grillowanie, wędzenie, suszenie, smażenie) $[9,25]$. Produktami wnoszącymi WWA do diety są tłuszcze roślinne i zwierzęce, produkty mięsne (szczególnie wędzone metodami tradycyjnymi) i rybne, owoce morza, warzywa, orzechy i rośliny strączkowe, a także kakao, herbata, suplementy diety. Ze względu na powszechne spożycie produkty zbożowe również uznawane są przez naukowców za źródło WWA w diecie człowieka $[8,11,22]$. Ze względu na lipofilowy charakter WWA kumulują się przede wszystkim w adipocytach. Kontaminacja produktów zbożowych wielopierścieniowymi węglowodorami aromatycznymi może wynikać z zanieczyszczenia atmosfery oraz z zastosowanych procesów przetwórczych [11, 13, 23, 25]. Europejski Urząd ds. Bezpieczeństwa Żywności (EFSA) nie wydał dotychczas regulacji prawnych odnośnie do maksymalnych dopuszczalnych zawartości benzo(a)pirenu $(\mathrm{BaP})$ oraz sumy benzo(a)pirenu, benzo(a)antracenu (BaA), benzo(b)fluorantenu (BbFA) i chryzenu (Chr) w produktach zbożowych, choć wprowadzenie tych limitów było przedmiotem dyskusji. Ze względu na potencjalnie wysoki udział produktów zbożowych (w tym pieczywa oraz zbożowych produktów śniadaniowych) w diecie człowieka niezbędne jest prowadzenie badań służących oszacowaniu poziomu zanieczyszczenia tych produktów wielopierścieniowymi węglowodorami aromatycznymi [7, 18, 25]. Również badania produktów zbożowych przeznaczonych dla niemowląt i małych dzieci $\mathrm{w}$ aspekcie zawartości WWA są istotne ze względu na szczególną szkodliwość WWA dla tej grupy konsumentów. Maksymalne dopuszczalne zawartości benzo(a)pirenu oraz sumy benzo(a)pirenu, benzo(a)antracenu, benzo(b)fluorantenu i chryzenu w produktach przeznaczonych do żywienia dzieci są określone w Rozporządzeniu Komisji (UE) 2015/1125 [20].

Celem pracy było określenie poziomu zanieczyszczenia różnych rodzajów handlowych produktów zbożowych (w tym produktów przeznaczonych dla niemowląt i dzieci) związkami z grupy WWA, tj. benzo(a)pirenem oraz sumą benzo(a)pirenu, benzo(a)antracenu, benzo(b)fluorantenu i chryzenu.

\section{Material i metody badań}

Materiał badany stanowiły dostępne na lokalnym rynku produkty zbożowe: chleby, pieczywo chrupkie, kasze, płatki zbożowe, musli (15 próbek) oraz kaszki zbożowe przeznaczone dla niemowląt i małych dzieci (15 próbek). Próbki pierwotne, tj. pobrane z jednej partii poszczególne sztuki lub zawartości opakowań jednostkowych produk- 
tów, łączono w próbkę zbiorczą o masie co najmniej 1 kg zgodnie z wytycznymi zawartymi w Rozporządzeniu Komisji (UE) nr 836/2011 [19]. Próbki zbiorcze ujednolicano przez zmielenie w młynku nożowym (LMN 100, TESTCHEM, Polska), przy czym próbki chleba wstępnie drobno krojono i krótko mrożono, natomiast w przypadku kaszek zbożowych próbki zbiorcze dokładnie mieszano. Następnie z próbek zbiorczych odważano próbki laboratoryjne.

Do oznaczenia zawartości benzo(a)pirenu, benzo(a)antracenu, benzo(b)fluorantenu oraz chryzenu zastosowano technikę wysokosprawnej chromatografii cieczowej z detekcją fluorescencyjną (HPLC-FLD). Metodyka przygotowania próbek do analizy chromatograficznej obejmowała zmydlanie próbki, ekstrakcję frakcji węglowodorowej i oczyszczanie jej w kolumnie wypełnionej tlenkiem glinu na drodze elucji eterem naftowym [24]. Analizy chromatograficzne przeprowadzano przy użyciu chromatografu cieczowego Dionex Ulti-Mate 3000 wyposażonego w pompę DGP 3600A, autosampler WPS - 3000 TSL, detektor fluorescencyjny Dionex FLD RF 2000 oraz kolumnę chromatograficzną Hypersil Green PAH $(250 \times 4,6 \mathrm{~mm}, 5 \mu \mathrm{m})$ wraz z prekolumną, (Thermo Scientific, Waltham, USA). Fazę ruchomą stanowił układ: acetonitryl / woda, przepływający z szybkością $1 \mathrm{ml} / \mathrm{min}$. Zastosowano elucję gradientową: $0 \div 15 \mathrm{~min}, 60: 40(\mathrm{v} / \mathrm{v}), 15 \div 53 \mathrm{~min}: 100: 0(\mathrm{v} / \mathrm{v})$ oraz następujące długości fali wzbudzenia i emisji (Ex/Em): dla BaA i Chr - 260/420 nm, dla BbFA i BaP 290/430 nm. Uzyskane dane przetwarzano i analizowano z wykorzystaniem oprogramowania Chromeleon (Dionex Corporation, Version 6,80 SP2 Build 2284, Dania). Wykreślono krzywe kalibracyjne, tj. zależności wielkości sygnału detektora od pól powierzchni pików substancji wzorcowych (AccuStandard, USA) na pięciu poziomach stężenia, w zakresie $0,2 \div 10,0 \mathrm{ng} / \mathrm{ml}$. Sekwencja pomiarowa obejmowała dozowanie: próbek ślepych, próbek właściwych, dwóch roztworów kalibracyjnych oraz próbek wzbogaconych dodatkiem wzorca. Sprawdzano jednorodność zakresu krzywych kalibracyjnych wszystkich oznaczanych związków i obliczano współczynniki zmienności dla stężeń granicznych. Do oceny jednorodności współczynników zmienności zastosowano test F-Snedecora oraz obliczono współczynnik korelacji r. Granicę wykrywalności (LOD) określano jako sumę wartości stanowiącej średnią zawartość danego analitu w próbce ślepej $\left(\mathrm{C}_{\mathrm{sr}}\right)$ i trzech odchyleń standardowych (3·SD) dla tej wartości, natomiast granicę oznaczalności (LOQ) jako $\mathrm{C}_{\text {śr }}+6 \mathrm{SD}$. Czułość metody stanowił stosunek przyrostu sygnału analitycznego do odpowiadającego mu przyrostu stężenia oznaczonego składnika (nachylenie krzywej kalibracyjnej). Selektywność metody potwierdzono poprzez badanie odzysku. Powtarzalność metody określano przez przeprowadzenie pełnej procedury analitycznej na próbkach kaszy kukurydzianej wzbogaconych mieszaniną wzorców. Ponadto w celu ustalenia zawartości WWA w matrycy wykonywano analizę zawartości badanych związków w próbce bez wzbogacenia oraz w próbkach ślepych. Odzysk i powtarzalność sprawdzano w przypadku każdej grupy 
badanych produktów. Wyniki oznaczeń uzyskane na etapie walidacji metody poddano analizie statystycznej. Przeprowadzono test Q-Dixona na obecność błędów grubych, a następnie określono dla każdego badanego poziomu stężeń danego analitu: współczynnik odzysku (poprawność), wariancję, odchylenie standardowe, współczynnik zmienności, niepewność standardową i rozszerzoną, przedział ufności oraz względne odchylenie standardowe powtarzalności. Oceny istotności różnic pomiędzy oznaczonymi zawartościami WWA w próbkach dokonano metodą porównań wielokrotnych wykorzystującą test Tukeya przy poziomie istotności 0,05 . Obliczenia statystyczne przeprowadzono przy użyciu programu Statistica 12 (StatSoft, Polska).

\section{Wyniki i dyskusja}

Wartości granicy wykrywalności (LOD), granicy oznaczalności (LOQ), powtarzalności (RSDr) oraz odzysków wyznaczone dla każdego oznaczanego związku na etapie walidacji metody (tab. 1) były zgodne z kryteriami zawartymi w Rozporządzeniu Komisji (UE) nr 836/2011 [19]. Krzywe kalibracyjne wyznaczone dla badanych związków w zakresie stężeń $0,20 \div 10,00 \mathrm{ng} / \mathrm{ml}$ opisano funkcjami liniowymi, a współczynniki korelacji przekraczały wartość 0,998 . Krzywe kalibracyjne wykorzystano do sprawdzenia powtarzalności oraz precyzji metody na trzech poziomach stężeń $[\mu \mathrm{g} / \mathrm{kg}]: 1,00,2,00$ i 20,00. Uzyskano w pełni akceptowalne wartości parametrów walidacyjnych, dlatego też stwierdzono możliwość stosowania niniejszej metody do oznaczania benzo(a)pirenu oraz sumy czterech WWA w zbożach i przetworach zbożowych.

Oszacowana na etapie walidacji niepewność oznaczenia wyniosła $15 \%$ dla każdego z badanych związków. Zgodnie z wymaganiami zawartymi w Rozporządzeniu Komisji (UE) $\mathrm{nr} 836 / 2011$ zestawione w tab. 2. i 3. wyniki uwzględniają rozszerzoną niepewność pomiaru przy zastosowaniu współczynnika rozszerzenia 2, co daje poziom ufności ok. $95 \%$ [19].

$\mathrm{Na}$ rys. 1. przedstawiono chromatogram mieszaniny wzorcowej oznaczanych WWA, natomiast na rys. 2. przedstawiono przykładowy chromatogram otrzymany w wyniku analizy próbki kaszki owsiano-pszennej ze śliwką.

Podane w tab. 2. i 3. wyniki oznaczania zawartości WWA zostały skorygowane o odzyski uzyskane w poszczególnych seriach pomiarowych zgodnie z wymaganiami Rozporządzenia Komisji (UE) nr 836/2011. We wszystkich przebadanych produktach zbożowych oznaczona zawartość sumy benzo(a)pirenu, benz(a)antracenu, benzo(b)fluorantenu i chryzenu wynosiła poniżej $1 \mu \mathrm{g} / \mathrm{kg}$ (tab. 2). 
Tabela 1. Parametry walidacyjne zastosowanej metody oraz kryteria jej oceny

Table 1. Validation parameters of method used and criteria of assessing it

\begin{tabular}{|c|c|c|c|c|c|}
\hline \multirow{2}{*}{\multicolumn{2}{|c|}{ Parametr / Parameter }} & \multicolumn{4}{|c|}{ Analit / Analyte } \\
\hline & & $\mathrm{BaA}$ & $\mathrm{Chr}$ & BbFA & $\mathrm{BaP}$ \\
\hline \multicolumn{2}{|c|}{$\begin{array}{l}\text { Liniowość - współczynnik korelacji liniowej } \\
\text { Linearity - correlation coefficient }\end{array}$} & 0,9999 & 1,0000 & 0,9999 & 1,0000 \\
\hline \multicolumn{2}{|c|}{$\begin{array}{l}\text { Czułość (slope) według równania regresji } \\
\text { Sensitivity (slope) by regression equation }\end{array}$} & 7,28 & 2,89 & 8,53 & 6,61 \\
\hline \multicolumn{2}{|c|}{$\begin{array}{l}\text { Granica wykrywalności (LOD) } \\
\text { Limit of detection (LOD) }[\mu \mathrm{g} / \mathrm{kg}]\end{array}$} & 0,18 & 0,18 & 0,18 & 0,18 \\
\hline \multicolumn{2}{|c|}{$\begin{array}{l}\text { Granica oznaczalności (LOQ) / Limit of quantification } \\
(\mathrm{LOQ})[\mu \mathrm{g} / \mathrm{kg}]\end{array}$} & 0,25 & 0,25 & 0,25 & 0,25 \\
\hline \multirow{3}{*}{$\begin{array}{l}\text { Odzysk } \\
\text { Recovery [\%] }\end{array}$} & poziom / level $[1,0 \mu \mathrm{g} / \mathrm{kg}]$ & 85,20 & 92,70 & 89,15 & 96,10 \\
\hline & poziom / level $[2,0 \mu \mathrm{g} / \mathrm{kg}]$ & 92,60 & 94,85 & 97,80 & 95,80 \\
\hline & poziom / level $[20,0 \mu \mathrm{g} / \mathrm{kg}]$ & 93,30 & 91,25 & 98,00 & 95,15 \\
\hline \multicolumn{2}{|c|}{ Powtarzalność $\operatorname{RSD}_{\mathrm{r}}{ }^{1} / \mathrm{R}_{\text {Repeatability RSD r [\% }}{ }^{1}$} & 8,8 & 8,7 & 12,4 & 8,9 \\
\hline \multicolumn{2}{|l|}{ HORRAT $_{\mathrm{r}}^{2}$} & 0,6 & 0,6 & 0,9 & 0,6 \\
\hline
\end{tabular}

Objaśnienia: ${ }^{1}$ Powtarzalność (względne odchylenie standardowe) / Repeatability (relative standard deviation), ${ }^{2}$ Rozporządzenie Komisji (EU) nr 836/2011 [19] / Commission Regulation (EU) No. 836/2011 [19]

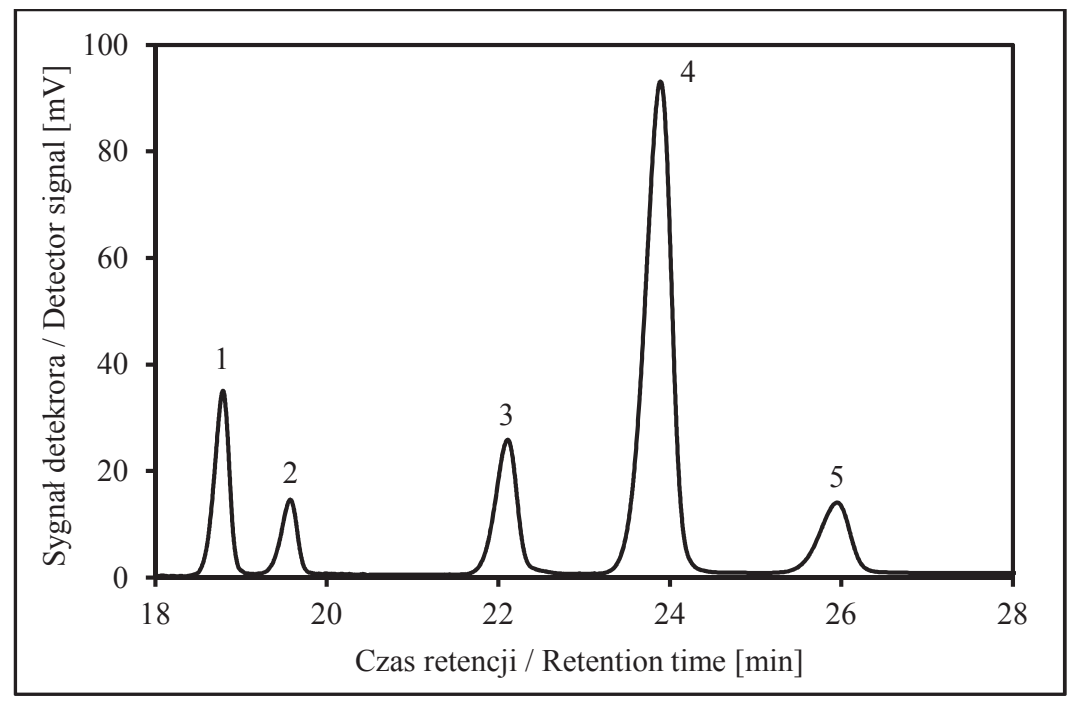

Rys. 1. Chromatogram mieszaniny wielopierścieniowych węglowodorów aromatycznych wzorca PAH Solution Mix (stężenie $1 \mathrm{ng} / \mathrm{ml}$ ): benzo(a)antracen (1), chryzen (2), benzo(b)fluoranten (3), benzo(k)fluoranten (4) oraz benzo(a)piren (5)

Fig. 1. HPLC-FLD chromatogram profile of PAH Solution Mix standard (concentration of $1 \mathrm{ng} / \mathrm{ml}$ ): benz(a)anthracene (1), chrysene (2), benzo(b)fluoranthene (3), benzo(k)fluoranthene (4), benzo(a)pyrene (5) 


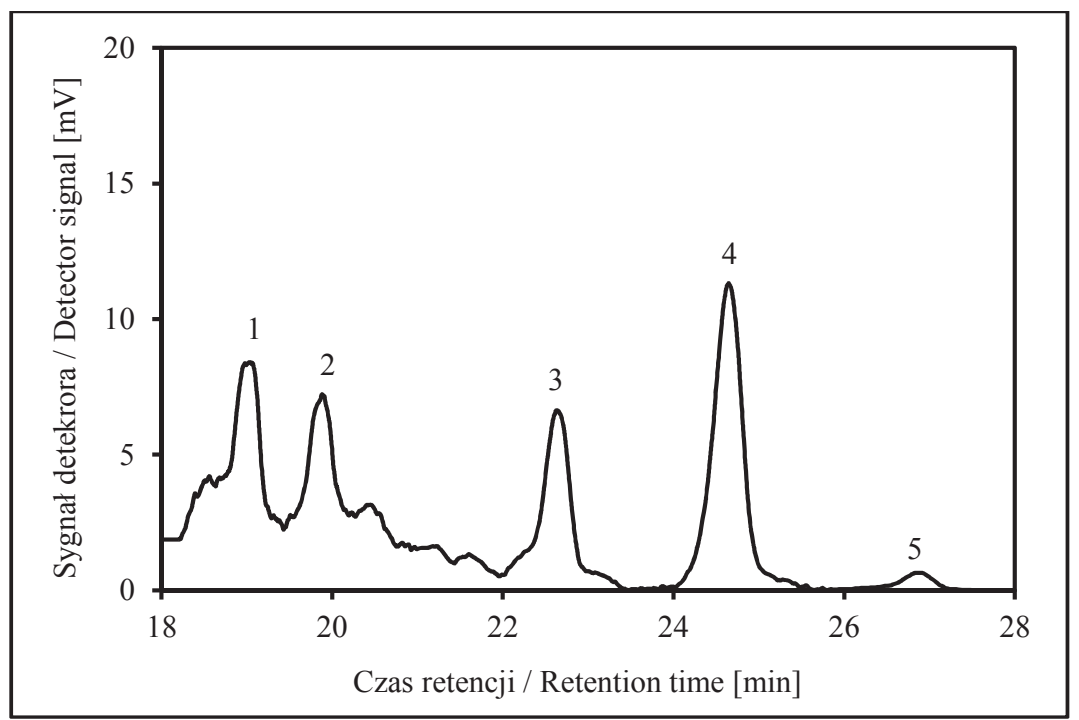

Rys. 2. Chromatogram próbki kaszki owsiano-pszennej ze śliwką

Fig. 2. HPLC-FLD chromatogram profile of oat-wheat gruel with plum for babies Objaśnienia jak pod rys. 1 / Explanatory notes as in Fig. 1

Tabela 2. Zawartość WWA w produktach zbożowych

Table 2. Content of PAHs in cereal products

\begin{tabular}{|c|c|c|c|c|c|}
\hline $\begin{array}{l}\text { Środek spożywczy } \\
\text { Foodstuff }\end{array}$ & $\mathrm{BaA}$ & Chr & $\mathrm{BbFA}$ & $\mathrm{BaP}$ & $\begin{array}{l}\Sigma 4 \mathrm{WWA} \\
\Sigma 4 \mathrm{PAHs}\end{array}$ \\
\hline $\begin{array}{l}\text { Płatki kukurydziane } \\
\text { Corn flakes }(\mathrm{n}=3)\end{array}$ & ND - 0,18 & ND & ND & ND & ND - 0,18 \\
\hline $\begin{array}{l}\text { Kasze (jęczmienna, } \\
\text { owsiana, kukurydziana) } \\
\text { Groats (barley, oats, } \\
\text { maize) }(\mathrm{n}=3)\end{array}$ & ND - 0,25 & ND - 0,33 & ND & ND & ND - 0,56 \\
\hline Chleb / Bread $(n=3)$ & ND & ND & ND & $0,19-0,24$ & ND - 0,21 \\
\hline $\begin{array}{l}\text { Pieczywo chrupkie } \\
\text { Crispbread }(\mathrm{n}=3)\end{array}$ & ND & ND - 0,25 & ND - 0,21 & ND - 0,21 & ND - 0,46 \\
\hline Musli / Muesli $(\mathrm{n}=3)$ & ND & ND - 0,49 & ND - 0,25 & ND & ND - 0,74 \\
\hline
\end{tabular}

Objaśnienia / Explanatory notes: W tabeli przedstawiono zawartości poszczególnych analitów $[\mu \mathrm{g} / \mathrm{kg}]$ : minimalne - maksymalne / Table shows contents of individual analytes $[\mu \mathrm{g} / \mathrm{kg}]$ : minimum - maximum;

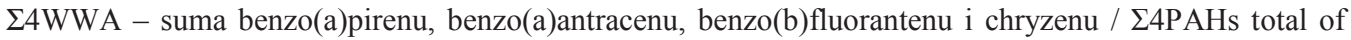
benzo(a)pyrene, benz(a)anthracene, benzo(b)fluoranthene and chrysene; $\mathrm{n}$ - liczba próbek / $\mathrm{n}$ - number of samples, ND - nie wykryto / not detected. 
W przypadku płatków kukurydzianych tylko w jednej próbce wykryto BaA i jego zawartość wynosiła $0,18 \mu \mathrm{g} / \mathrm{kg}$, natomiast w pozostałych próbkach nie wykryto badanych poliarenów. Obecność BaA i Chr stwierdzono w kaszy kukurydzianej i owsianej (w ilości wynoszącej średnio $0,23 \mu \mathrm{g} \mathrm{BaA} / \mathrm{kg}$ oraz $0,32 \mu \mathrm{g} \mathrm{Chr} / \mathrm{kg}$ ). W średnio wypieczonym pieczywie mieszanym pytlowym zawartość BaP wynosiła $0,19 \div 0,24 \mu \mathrm{g} / \mathrm{kg}$ i była porównywalna do ilości oznaczonej przez Ciemniak i Witczak [6] w średnio i mocno wypieczonym pieczywie mieszanym. W badaniach nad wpływem procesu pieczenia na zawartość WWA w pieczywie [6] stwierdzono, że wraz ze zwiększającym się stopniem wypieczenia zwiększa się zawartość WWA w gotowym produkcie. Poziom zanieczyszczenia skórki, tj. najbardziej wypieczonej warstwy chleba, bułek i bagietek, związkami WWA był wyższy niż poziom zanieczyszczenia miękiszu. Stwierdzono również liniową współzależność pomiędzy zawartością WWA w skórce i w miękiszu [6]. W innych badaniach [3] śladowe ilości poliarenów wykryto również w mące. Maksymalna zawartość $\mathrm{BaP}$ w próbkach zarówno mąki pszennej chlebowej typu 750, jak i pszennej razowej typu 2000 wynosiła $0,12 \mu \mathrm{g} / \mathrm{kg}$ [3]. Występowanie WWA w pieczywie może wynikać z zanieczyszczenia mąki, jednak głównymi czynnikami wpływającymi na obecność WWA w pieczywie są parametry procesu pieczenia oraz rodzaj czynnika grzewczego. W tym przypadku szczególną uwagę należy zwrócić na kontrolę procesu przebiegającego w piecach opalanych drewnem [14]. W nowoczesnych piekarniach proces wypieku jest ściśle kontrolowany, by nie nastąpiło zbyt mocne wypieczenie bądź przypalenie chleba. Ciecierska i Obiedziński [2] wykazali, że na powstawanie WWA w pieczywie wypiekanym w piecach cyklotermicznych znacząco wpływa zastosowana temperatura. Autorzy ci stwierdzili również, że występujące w surowcach i w wyrobach gotowych poliareny należą głównie do tzw. lekkich WWA. Ciemniak i Chrąchol [4] stwierdzili, że zawartość BaP w przypalonych fragmentach chleba szesnastokrotnie przekroczyła zawartość tego związku w częściach odpowiednio wypieczonych. Europejski Urząd ds. Bezpieczeństwa Żywności (EFSA) podaje, że zawartość BaP w chlebach osiąga maksymalnie $0,5 \mu \mathrm{g} / \mathrm{kg}$, przy wartości mediany $0,18 \mu \mathrm{g} / \mathrm{kg}$ [8], a zatem wyniki badań przedstawione w niniejszej pracy są zbliżone do tych danych. Również publikowane przez Kacmaz i wsp. [12] wyniki badań świadczą o niskim poziomie zanieczyszczenia poliarenami próbek chleba i zbożowych produktów śniadaniowych dostępnych w obrocie handlowym. W badaniach cytowanych wyżej autorów [12] średnie sumy zawartości czterech WWA w próbkach chleba oraz zbożowych produktów śniadaniowych mieściły się w zakresach odpowiednio: $0,11 \div$ $0,22 \mu \mathrm{g} / \mathrm{kg}$ oraz $0,23 \div 0,87 \mu \mathrm{g} / \mathrm{kg}$. Również w pieczywie chrupkim oznaczono mało badanych poliarenów - maksymalna zawartość chryzenu, benzo(b)fluorantenu oraz benzo(a)pirenu wynosiła $0,21 \div 0,25 \mu \mathrm{g} / \mathrm{kg}$. W żadnej z przebadanych próbek nie wykryto benzo(a)antracenu. Produkcja wyrobów ekstrudowanych wiąże się z zastosowaniem temperatury wynoszącej do $200{ }^{\circ} \mathrm{C}$ i ciśnienia - do $20 \mathrm{MPa}$, a zatem parametry 
procesu ekstruzji nie powinny wpływać na powstawanie tzw. ciężkich WWA w pieczywie chrupkim.

Najwięcej badanych poliarenów oznaczono w próbce musli, w skład którego wchodziły płatki pszenne (48 \%) oraz płatki owsiane pełnoziarniste (30\%), a także suszone rodzynki i orzechy laskowe. Zawartość chryzenu wyniosła $0,49 \pm 0,07 \mu \mathrm{g} / \mathrm{kg}$, a benzo(b)fluorantenu $-0,25 \pm 0,04 \mu \mathrm{g} / \mathrm{kg}$, natomiast nie wykryto benzo(a)antracenu i benzo(a)pirenu. Spośród pozostałych próbek musli w jednej nie wykryto badanych związków, natomiast w drugiej oznaczono tylko chryzen $(0,49 \pm 0,07 \mu \mathrm{g} / \mathrm{kg})$. Ciemniak i Chrąchol [4] wykazali bardzo dużą rozbieżność pod względem zawartości poszczególnych WWA w próbkach musli wyprodukowanych przez różnych producentów. Oznaczone przez nich maksymalne zawartości poliarenów $(\mathrm{BaA}-3,6 \mu \mathrm{g} / \mathrm{kg}, \mathrm{Chr}$ $-1,0 \mu \mathrm{g} / \mathrm{kg}, \mathrm{BbFA}-1,8 \mu \mathrm{g} / \mathrm{kg}, \mathrm{BaP}-1,8 \mu \mathrm{g} / \mathrm{kg}$ ) były zdecydowanie większe niż te wykazane w niniejszej pracy (tab. 2).

Tabela 3. Zawartość limitowanych WWA w produktach dla niemowląt i dzieci $[\mu \mathrm{g} / \mathrm{kg}]$

Table 3. Contents of limited PAHs in product for infants and babies $[\mu \mathrm{g} / \mathrm{kg}]$

\begin{tabular}{|c|c|c|c|c|c|}
\hline $\begin{array}{l}\text { Środek spożywczy } \\
\text { Foodstuff }\end{array}$ & $\mathrm{BaA}$ & $\mathrm{Chr}$ & BbFA & $\mathrm{BaP}$ & $\Sigma 4 \mathrm{WWA}$ \\
\hline $\begin{array}{l}\text { Kaszki zbożowe } \\
\text { Cereal gruels }(\mathrm{n}=3)\end{array}$ & ND - 0,18 & ND - 0,66 & ND & $\mathrm{ND}$ & ND - 0,87 \\
\hline $\begin{array}{l}\text { Kaszki zbożowe } \mathrm{z} \text { owocami } \\
\text { Cereal gruels with fruits }(\mathrm{n}=3)\end{array}$ & ND - 0,23 & ND - 0,32 & ND - 0,31 & $\mathrm{ND}$ & ND - 0,86 \\
\hline $\begin{array}{l}\text { Kaszki zbożowe } \mathrm{z} \text { lipą } \\
\text { Cereal gruels with linden }(\mathrm{n}=3)\end{array}$ & ND & ND - 0,58 & ND & $\mathrm{ND}$ & ND $-0,58$ \\
\hline $\begin{array}{l}\text { Kaszki mleczno-zbożowe } \\
\text { Milk-cereal gruels }(\mathrm{n}=3)\end{array}$ & ND & ND & ND & $\mathrm{ND}$ & ND \\
\hline $\begin{array}{l}\text { Kaszki mleczno-zbożowe z owocami } \\
\text { Milk-cereal gruels with fruits }(\mathrm{n}=3)\end{array}$ & ND & ND & ND & ND & ND \\
\hline
\end{tabular}

Objaśnienia jak pod tab. 2. / Explanatory notes as in Tab. 2.

We wszystkich przebadanych kaszkach zbożowych i kaszkach mlecznozbożowych oznaczone zawartości benzo(a)pirenu oraz sumy benzo(a)pirenu, benzo(a)antracenu, benzo(b)fluorantenu i chryzenu (tab. 3) mieściły się w granicach dopuszczalnego poziomu (1 $\mu \mathrm{g} / \mathrm{kg}$ ) określonego w Rozporządzeniu (UE) 2015/1125 [20]. Tylko w trzech z piętnastu przebadanych próbek kaszek stwierdzono obecność BaA, Chr i BbFA na poziomie równym granicy wykrywalności lub wyższym. Benzo(a)antracenu oraz chryzenu oznaczono odpowiednio: $0,18 \mu \mathrm{g} / \mathrm{kg}$ i $0,66 \mu \mathrm{g} / \mathrm{kg}$ w kaszce zbożowej zawierającej w swoim składzie grysik pszenny i ryżowy, a w kaszce owsiano-pszennej ze śliwką odpowiednio: $0,23 \mu \mathrm{g} / \mathrm{kg}$ i $0,32 \mu \mathrm{g} / \mathrm{kg}$. W tej ostatniej oznaczono także BbFA w ilości $0,31 \mu \mathrm{g} / \mathrm{kg}$. Benzo(a)pirenu nie wykryto w żadnej 
z przebadanych kaszek zbożowych i mleczno-zbożowych, także również w tych z dodatkiem owoców lub wzbogaconych ekstraktem kwiatu lipy. Podobne do powyższych małe zawartości benzo(a)pirenu oraz sumy benzo(a)pirenu, benzo(a)antracenu, benzo(b)fluorantenu i chryzenu w preparatach do żywienia niemowląt i małych dzieci wykazano we wcześniejszych badaniach $[1,10]$. Według Kalickiej i Zachary [10] oraz Ciecierskiej i Obiedzińskiego [1] zarówno w próbkach przetworzonej żywności na bazie zbóż dla niemowląt i małych dzieci, jak i w próbkach mleka początkowego i następnego poziom zanieczyszczenia WWA jest niewykrywalny lub bardzo niski.

Z kolei Ciemniak i Ochwat [5] stwierdzili występowanie kancerogennych WWA w kaszkach ryżowych przeznaczonych dla dzieci w ilości $5 \div 7,4 \%$ (w tym BaP w ilości $0,04 \div 0,09 \mu \mathrm{g} / \mathrm{kg}$ ). Są to jednak ilości WWA znacznie niższe od tych oznaczonych w ryżu $[16,21]$.

\section{Wnioski}

1. Zawartość banzo(a)pirenu oraz sumy benzo(a)pirenu, benzo(a)antracenu, benzo(b)fluorantenu i chryzenu w żadnej z badanych próbek produktów zbożowych nie przekroczyła $1 \mu \mathrm{g} / \mathrm{kg}$, tj. ilości stanowiącej najwyższy dopuszczalny poziom w produktach przeznaczonych dla niemowląt i małych dzieci zgodnie z wymaganiami Rozporządzenia UE 2015/1125.

2. Oznaczane poliareny wykryto $\mathrm{w}$ jedenastu handlowych produktach zbożowych spośród piętnastu badanych. W płatkach kukurydzianych oraz w chlebach stwierdzono mniejsze zawartości sumy benzo(a)pirenu, benzo(a)antracenu, benzo(b)fluorantenu i chryzenu niż w kaszach, pieczywie chrupkim i musli.

3. Benzo(a)antracen, benzo(b)fluoranten i chryzen wykryto w trzech kaszkach zbożowych i mleczno-zbożowych przeznaczonych dla niemowląt i małych dzieci, natomiast w żadnej z badanych kaszek nie wykryto benzo(a)pirenu.

Podziękowania: Autorzy pracy dziękują mgr inż. Monice Hoty oraz Małgorzacie Kucab za pomoc techniczna przy wykonaniu badań.

\section{Literatura}

[1] Ciecierska M., Obiedziński M.: Występowanie WWA w preparatach do początkowego i dalszego żywienia niemowląt oraz w żywności dla małych dzieci w odniesieniu do wymagań prawa żywnościowego Unii Europejskiej. Żywność. Nauka. Technologia. Jakość, 2009, 1 (62), 37-45.

[2] Ciecierska M., Obiedziński M.: Polycyclic aromatic hydrocarbons in the bakery chain. Food Chem., 2013, 141, 1-9.

[3] Ciemniak A.: Wpływ zabiegów kulinarnych oraz procesów technologicznych na zawartość wielopierścieniowych węglowodorów aromatycznych w żywności. Rozprawa habilitacyjna, Wyd. ZUT, Szczecin 2010. 
[4] Ciemniak A., Chrąchol L.: Wielopierścieniowe węglowodory aromatyczne (WWA) w zbożowych produktach śniadaniowych. Roczniki PZH, 2008, 59 (3), 301-307.

[5] Ciemniak A., Ochwat M.A.: Porównanie zawartości wielopierścieniowych węglowodorów aromatycznych w wybranych produktach przeznaczonych do żywienia niemowląt i małych dzieci. Bromat. Chem. Toksykol., 2008, XLI (1), 73-79.

[6] Ciemniak A., Witczak A.: Porównanie zawartości wielopierścieniowych węglowodorów aromatycznych (WWA) w pieczywie. Roczniki PZH, 2010, 61 (2), 135-140.

[7] European Food Safety Authority: Polycyclic Aromatic Hydrocarbons in Food. Scientific Opinion of the Panel on Contaminants in the Food Chain (Question N ${ }^{\circ}$ EFSA-Q-2007-136). The EFSA Journal, 2008, 724, 1-114.

[8] European Food Safety Authority: Findings of the EFSA Data Collection on Polycyclic Aromatic Hydrocarbons in Food. [online]. Dostęp w Internecie [15.02.2017]: http://www.efsa.europa.eu/ en/scdocs/doc/33r.pdf

[9] FAO/WHO: Food standards programme. Codex Alimentarius Commission. Codex committee on contaminants in foods, $8^{\text {th }}$ Session, Hague, Netherlands, 31 March -4 April 2014. Working document for information and use in discussions related to contaminants and toxins in the GSCTFF.

[10] Kalicka D., Zachara A.: Contamination of polycyclic aromatic hydrocarbons (PAHs) in products for infants and young children in the Podkarpackie region. In: Food Quality and Perspectives. XX Conference of Young Researchers - 4th International Session. Eds. M. Wesołowska, M. Dżugan. Wyd. Oddz. Rzeszowski PTTŻ, PTCh, URz, Rzeszów 2015, s. 55.

[11] Kubiak M.S.: Wielopierścieniowe węglowodory aromatyczne (WWA) - ich występowanie w środowisku i w żywności. Prob. Hig. Epidemiol., 2013, 94 (1), 31-36.

[12] Kacmaz S., Zelinkova Z., Wenzl T.: Rapid and sensitive method for the determination of four EU marker polycyclic aromatic hydrocarbons in cereal-based foods using isotope-dilution GC/MS. Food Addit. Contam., 2016, 33 (4), 631-638.

[13] De Lima F.R., Dionello R.G., Peralba M.C.R., Barrionuevo S., Radunz L.L., Reichert Júnior F.W.: PAHs in corn grains submitted to drying with firewood. Food Chem., 2017, 215, 165-170.

[14] Orecchio S., Papuzza V.: Levels, fingerprint and daily in bread baked using wood as fuel. J. Hazard. Mater., 2009, 164 (2-3), 876-883.

[15] Nowak A., Libudzisz Z.: Karcynogeny w przewodzie pokarmowym człowieka. Żywność. Nauka. Technologia. Jakość, 2008, 4 (59), 9-25.

[16] Perelló G., Martǐ-Cid R., Castell V., Llobet J.M., Domingo J.L.: Concentrations of polybrominated diphenyl ethers, hexachlorobenzene and polycyclic aromatic hydrocarbons in various foodstuffs before and after cooking. Food Chem. Toxicol., 2009, 47, 709-715.

[17] Rozporządzenie Komisji (WE) nr 1881/2006 z dnia 19 grudnia 2006 r. ustalające najwyższe dopuszczalne poziomy niektórych zanieczyszczeń w środkach spożywczych. Dz. Urz. UE L 364, s. $5, \mathrm{z}$ dn. 20.12.2006 z późn. zm.

[18] Rozporządzenie Komisji (WE) nr 835/2011 z dnia 19 sierpnia 2011 r. zmieniające rozporządzenie (WE) nr 1881/2006 odnośnie do najwyższych dopuszczalnych poziomów wielopierścieniowych węglowodorów aromatycznych w środkach spożywczych. Dz. Urz. UE L 215, s.4, z dn. 20.08.2011.

[19] Rozporządzenie Komisji (WE) nr 836/2011 z dnia 19 sierpnia 2011 r. zmieniające rozporządzenie nr 333/2007 z dnia 28 marca 2007 r. ustanawiające metody pobierania próbek i metody analiz do celów urzędowej kontroli poziomów ołowiu, kadmu, rtęci, cyny nieorganicznej, 3-MCPD i benzo[a]pirenu w środkach spożywczych. Dz. Urz. UE L 215, s. 9, z dn. 20.08.2011.

[20] Rozporządzenie Komisji (UE) 2015/1125 z dnia 10 lipca 2015 r. zmieniające rozporządzenie (WE) nr 1881/2006 w odniesieniu do najwyższych dopuszczalnych poziomów wielopierścieniowych węglowodorów aromatycznych w katsuobushi (suszony bonito) oraz niektórych wędzonych śledziach bałtyckich. Dz. Urz. UE L 215, s. 4 , z dn. 20.08.2011.

[21] Tao S., Jiao X.C., Chen S.H., Liu W.X., Coveney Jr R.M., Zhu L.Z., Luo Y.M.: Accumulation and distribution of polycyclic aromatic hydrocarbons in rice (Oryza sativa). Environ. Pollut., 2006, 140, 406-415. 
[22] Wieczorek J., Wieczorek Z.: Pobranie wielopierścieniowych węglowodorów aromatycznych z żywnością. Bromat. Chem. Toksykol., 2011, XLIV (3), 725-731.

[23] World Health Organization, International Agency for Research on Cancer: IARC Monographs on the Evaluation of Carcinogenic Risks to Humans. Some Non-heterocyclic Polycyclic Aromatic Hydrocarbons and Some Related Exposures. IARC, Lyon 2010, p. 92.

[24] Zachara A., Gałkowska D., Juszczak L.: Method validation and determination of polycyclic aromatic hydrocarbons in vegetable oils by HPLC-FLD. Food Anal. Methods, 2017, 10, 1078-1086.

[25] Zachara A., Juszczak L.: Zanieczyszczenie żywności wielopierścieniowymi węglowodorami aromatycznymi - wymagania prawne i monitoring. Żywność. Nauka. Technologia. Jakość, 2016, 3 (106), 5-20.

\title{
OCCURRENCE OF POLYCYCLIC AROMATIC HYDROCARBONS IN SELECTED CEREAL PRODUCTS
}

\author{
S u m m a ry
}

In the paper, the results are presented of the research the objective of which was to determine levels of contamination in different types of cereals products contaminated with the compounds from a group of polycyclic aromatic hydrocarbons (PAHs), i.e. with benzo(a)pyrene and with the total of benzo(a)pyrene, benz(a)anthracene, benzo(b)fluoranthene, and chrysene. In the Commission Regulation (UE) No. 2015/1125 the limits are set for the content of those compounds in infant and baby foods. The research materials were commercial-off-the-shelf (COTS) cereal flakes, groats, bread, crispbread, and muesli as well as infant and baby products: cereal gruels and milk-cereal gruels. To determine the PAHs, a high performance liquid chromatography was applied and a fluorescence detection method (HPLC-FLD) after samples saponification followed by the extraction and clean-up of the hydrocarbon fraction. The values of the detection and quantification limits, determined at the stage of validating the method, were 0.18 and $0.25 \mu \mathrm{g} / \mathrm{kg}$, respectively, and they were significantly lower than the respective maximum values as set in the Commission Regulation (EU) No. 836/2011. The PAHs under study were found in $73 \%$ of the cereals products; however, their content did not exceed $1 \mu \mathrm{g} / \mathrm{kg}$. Compared to groats, crispbread, and muesli, the contents of the total of the four PAHs found in the corn flakes samples were lower. Benz(a)anthracene, benzo(b)fluoranthene, and chrysene were detected in $20 \%$ of the analysed infant and baby gruels while benzo(a)pyrene was found in none of them.

Key words: polycyclic aromatic hydrocarbons (PAHs), benzo(a)pyrene, cereal products, foods for children 